\title{
EFFECT OF RED DEER GRAZING ON ALPINE HAY MEADOWS: BIODIVERSITY AND MANAGEMENT IMPLICATIONS
}

\author{
CAtorci, A. ${ }^{1}$ - TARdella, F. M. ${ }^{1}$ - Piermarteri, K. ${ }^{2 *}$ - PenNesi, R. ${ }^{1}-$ Malatesta, L. ${ }^{2}-$ \\ CORAZZA, $\mathrm{M}^{3}-\mathrm{SCOCCO}, \mathrm{P}^{1}$ \\ ${ }^{I}$ Plant Diversity and Ecosystems Management unit, School of Biosciences and Veterinary \\ Medicine, University of Camerino \\ via Pontoni 5, 62032 Camerino (MC), Italy \\ (phone: +39-0737-404511) \\ ${ }^{2}$ School of Advanced Studies, University of Camerino \\ via Camillo Lili 55, 62032 Camerino (MC), Italy \\ ${ }^{3}$ Department of Biological, Geological and Environmental Sciences, University of Bologna \\ Botanic Garden via Irnerio 42, 40126 Bologna (B0), Italy \\ Corresponding author \\ e-mail: karina.piermarteri@unicam.it
}

(Received $2^{\text {nd }}$ Jul 2015; accepted $23^{\text {rd }}$ Feb 2016)

\begin{abstract}
Large mammalian herbivores are keystone species affecting the biodiversity and functioning of ecosystems, since herbivory directly influences plant species competitive ability. Thus, when managing habitats for conservation it is crucial to understand the selection patterns of large herbivores and their effect on plant diversity and assemblage. With this aim, we studied a pastoral system placed in centraleastern Alps, comparing late mowing with grazing by red deer.

We found that, with high stocking rates, red deer significantly affects the species and functional composition of alpine productive pastures, mostly by competitive exclusion of subordinate species due to the spread of poorly palatable, competitive, stress-tolerant tall grasses with strong avoidance strategies. We argued that grazing by red deer with high stocking rates is harmful when acts on formerly managed meadows, while it has a positive impact on plant diversity of long-term abandoned grasslands. Our results indicated that grazing by red deer with high stoking rates hinders the spread of successional/ruderal species, but allows the establishment of competitive dominant tall grasses. Our findings also confirmed the hypothesis that the impact of red deer on grassland biodiversity follows the intermediate disturbance hypothesis.
\end{abstract}

Keywords: herbivory; grassland management; large herbivores; disturbance intensity; competitive exclusion

\section{Introduction}

Large mammalian herbivores are keystone species, which affect the biodiversity and functioning of ecosystems (Rooney and Waller, 2003). Thus, when managing habitats for conservation it is crucial to understand the selection pattern of large herbivores and their effect on plant diversity and assemblage. One of the most widespread European wild large herbivores is red deer (Cervus elaphus L.). Red deer is an Intermediate Opportunistic Mixed feeding type (Hoffmann, 1989); it practices a marked degree of forage selectivity related to forage availability (Johnson et al., 2001) and quality (Wallis DeVries et al., 1999), and to the species composition of plant communities (Bellu et al., 2012). Red deer discriminates among pasture species, generally preferring legumes and forbs to grasses and avoiding fibers as much as possible (Kay, 1985). This ungulate shows remarkable anatomical modification of digestive apparatus linked to forage 
quality, such as the Surface Enlargement Factor and vascular development variation of rumen papillae (Hofmann, 1989), following the general trend of ruminants, in which modifications of rumen mucosa related to both pasture vegetative cycle and grazing on poorly palatable grasses occur (Scocco et al., 2013).

Herbivory directly affects the growth, reproduction, and survival of plants by consuming leaves, stems, flowers, and fruits, thus directly influencing plant species competitive ability (Lauenroth and Aguilera, 1998). Moreover, it was stated that differential defoliation leads to spatial variation in plant growth (Skarpe and Hester, 2008), nutrient cycling (Holdo et al., 2007) and, ultimately, vegetation structure (Wieren and Bakker, 2008). Therefore, grazing may lead to the variation in the abundance of plant species over longer periods by affecting competition processes (Augustine and Mc Naughton, 1998). Plants react against grazers by means of avoidance and tolerance strategies. Grazing avoidance involves mechanisms that reduce the probability and severity of grazing (mechanical and chemical defence or escape strategy), while tolerance consists in mechanisms that promote re-growth following defoliation (Briske, 1996). The effectiveness of these strategies depends on the level of primary production, the intensity of defoliation, and the foraging behaviour of the herbivores (Bullock, 1996). Defence mechanisms (besides resources acquisition and storage ability) of plants depend on their traits, which may be considered as biological characteristics of species responding to the dominant processes in an ecosystem (Lavorel et al., 1997). Trait assessment gives information about the mechanisms of processes like management treatments (Bullock et al., 2001), allowing to understand the changes acting in complex ecosystems and to predict vegetation modifications induced by different management types (Noble and Gitay, 1996).

Previous research on deer management largely focused on the effects of this ungulate on plant populations and habitat conditions and aimed to understand how to limit the impacts of these animals on ecosystem components and functions (Cote et al., 2004). In the last decades several studies were carried out worldwide about the impact of deer population on forest understory (e.g. Gill and Beardall, 2001), forest regeneration (e.g. Hegland et al., 2013), and dynamic processes of plant communities (e.g. Chollet et al., 2013). However, little is known about the impact of red deer on semi-natural herbaceous communities, especially as regards plant functional traits. Anyhow, this is a key issue, since the recent expansion of red deer resulted in an increased use of open areas with impacts, for instance, on forage production (Marchiori et al., 2012) and plant diversity (Schütz et al., 2003). Therefore, detailed knowledge about the effects of red deer grazing on biodiversity and trait-based species assemblage of pastures are needed to achieve a broader ecosystem perspective of grazing by wild herbivores (Mysterud, 2006). In this regard, detecting in which direction wild herbivores change the plant species assemblage is still a partially open question, since it depends on several factors such as herbivore species (Albon et al., 2007) and density (Putman, 2011; Ferretti et al., 2015), plant community type, productivity and composition (Bullock et al., 1996). Competition among sympatric wild herbivores (Lovari et al., 2014) and land use history (Gustavson et al., 2007) are key factors as well. Schütz et al. (2003) suggested that the red deer impact on grasslands follows the intermediate disturbance hypothesis (Grime, 2001). To test this statement, we compared the effects of late mowing and grazing by red deer. Late mowing is a non-selective type of disturbance (Kohler et al., 2005) that makes available to plants a long period to complete their reproductive cycle, leading to a complex trait-determined use of different temporal and spatial niches (Catorci et al., 
2014b), thus acting like an intermediate disturbance intensity in productive environments. Instead, red deer browsing with higher density (e.g. more than 0.1 individuals/hectare - Putman et al., 2011; Ferretti et al., 2015; the average red deer density in the Alps is generally lower than 0.2 individuals/hectare - Marchiori et al., 2012), may be considered a high disturbance intensity, produced by an intermediate, opportunistic, mixed feeder, with a marked degree of forage selectivity (Hofmann, 1989), thus potentially leading to a high spatial heterogeneity of vegetation (Adler et al., 2001). Red deer selectivity changes at both large (plant community level) and small scale (patch and individual levels) due to differences in landscape and plant community mosaics (Hester et al., 1999; Cougenhour, 1991). Therefore, in order to assess the traitrelated direction of changes in grassland composition caused by herbivory of red deer, we chose experimental controlled conditions, with captive red deer grazing exclusively on former hay meadows. In such experimental conditions we hypothesized that longterm grazing by reed deer with high stocking rates: i) decreases species richness and diversity; ii) alters the composition of pastures fostering the spread of poorly palatable species with strong competitive strategies, leading to the exclusion of the least competitive ones; iii) leads to a decrease of the pasture feed value through the reduction of the most palatable species (i.e. legumes and forbs).

\section{Material and methods}

\section{Study area}

The study was conducted in an old, traditional pastoral system of the Paneveggio Pale San Martino Natural Park, in the central-eastern Italian Alps. The study area $\left(46^{\circ} 18^{\prime} 22^{\prime}\right.$ ' $\mathrm{N}, 11^{\circ} 44^{\prime} 29^{\prime}$ ' $\left.\mathrm{E}\right)$ is situated at $1500 / 1550 \mathrm{~m}$ a.s.l., on gentle south-southeastfacing slopes. The entire study site underwent the same management type until 1971 (mowing and fertilisation with mature manure after hay removal), when part of it was fenced and began to host a population of captive red deer.

In the fenced area (hereafter referred to as site A) annual cutting regime was imposed from late August to early September until 1990. In the fenced stand the manuring regime was continued during the 1980s. Starting from 1990 any type of management ceased. Red deer have not feed supply from May to late September, and are free to feed on fenced pastures ( 7 hectares). The stocking rate was very high, that is 0.4-0.5 individuals/hectare (see Schütz et al., 2003).

Differently, in the other part of the study area (6 hectares, hereafter referred to as site B), traditional mowing activities continued throughout the last forty years; the meadows are fertilized with manure annually and undergo hay cut in August (that is late mowing). Hay is stored and used during winter to feed deer.

\section{Experimental design and data collection}

We laid 43 plots of $50 \times 50 \mathrm{~cm}$ in the grazed site and 34 in the mowed one. Lower left-hand corners of plots were placed at the nodes of a $50 \times 50 \mathrm{~m}$ grid overlaid to the study area.

In each plot, we collected data on cover percentage of species, altitude (m a.s.l.), slope aspect (azimuth degrees) and slope angle (vertical degrees). Field relevés were carried out from late June to early July 2014. We selected a set of traits (life form, horizontal and vertical space occupation, type of vegetative propagation) focusing on 
plant competitive ability and resistance to disturbance (Díaz et al., 1999; Liira and Zobel, 2000; Cornelissen et al., 2003; Garnier et al., 2007). All traits were treated as categorical variables. A description of each trait, with the main associated plant functions, a list of the respective states and data sources is reported in the Appendix 1.

We used the Grime's strategies (Grime, 2001) to assess difference between treatments due to plant ecological adaptations and resource acquisition strategies. The CSR model postulates the existence of three primary plant strategies: competitors (C), stress-tolerators (S), and ruderals (R). In addition, the CSR model provides the existence of secondary strategies corresponding to the various trade-offs in adaptation to competition, stress and disturbance: competitive ruderals (CR), stress-tolerant ruderals (SR), stress-tolerant competitors (CS), and competitive stress-tolerant ruderals (CSR). Even though the ability of CSR theory to predict variation in species composition along environmental gradients, such as altitudinal and temperature ones, has been questioned (e.g. van der Werf et al., 1998), it has nonetheless been demonstrated to be a useful tool for assessing and quantifying variations along successional gradients (Caccianiga et al., 2006). Information about species life strategies (Grime, 1974, 2001) were gathered from Grime et al. (1988), BiolFlor database (Klotz et al., 2002), or checked by field observations, on the basis of the criteria and examples provided by Grime et al. (1988) and Grime (2001). Finally, since reed deer have a diet preference for forbs and legumes, we distinguished three functional groups: leguminous species, forbs, and graminoids.

In order to have an approximation of difference in soil nutrient content between sites, we used the nitrogen (N) Ellenberg's indicator values (Ellenberg 1974, 1996; Ellenberg et al., 1992) since Ellenberg's indicators have proven useful in analyzing the drivers of vegetation change (i.e. McCollin et al., 2000; Godefroid and Dana, 2007; Klaus et al., 2012). We drew N values from Pignatti (2005).

Species nomenclature followed Conti et al. (2005) and in some cases the International Plant Names Index (http://www.ipni.org).

\section{Data analysis}

To ascertain whether management type affects the species composition of grasslands, we performed canonical redundancy analysis (RDA) of the "plots $\mathrm{x}$ species cover (percentage)" matrix, constrained by land use (i.e. grazing and mowing conditions). Prior to RDA, cover data matrices were Hellinger-transformed to avoid considering double absence as a resemblance between sites (Legendre and Gallagher, 2001).

To assess the species diversity between the grazed and mowing conditions, we computed the Shannon-Wiener $\left(\mathrm{H}^{\prime}\right)$, Gini-Simpson (D) and Shannon Evenness $\left(\mathrm{E}_{\mathrm{H}}\right)$ indices.

To identify the indicator species of each management condition, we performed Indicator species analysis (ISA) on the matrix "relevés x species cover (percentage)", using management as grouping variable. ISA is a non-parametric method for identifying those items that show significantly preferential distribution (in terms of frequency and abundance). An Indicator Value (IV) is calculated by multiplying the relative abundance of each item in a particular group and the relative frequency of the item occurrence in the sample of that group (Dufrêne and Legendre, 1997). The number of randomized IVs higher than the observed ones is used to calculate the probability value (McCune and Grace, 2002). The statistical significance $(\mathrm{P}<0.05)$ of the observed maximum IVs was tested using permutation tests with 4,999 iterations. We considered of interest only Indicator values higher than 20 . 
We assumed that the indicator species set is a key tool to understand the changes in plant community composition, as the management modification mostly affects frequency and abundance of species identified as indicators species by ISA. Therefore, to verify whether functional composition of plant communities was related to changes in grassland management, the above-mentioned plant traits and Grime's strategies were attributed to the indicator species highlighted by ISA. To transform trait and Grime's strategies binary data (presence/absence) into quantitative data (i.e. aggregated cover values of each trait / strategy), we multiplied the "plots x indicator species cover" matrix by the "species $x$ trait state / strategy (presence/absence)" matrix to provide a "plots $x$ trait state / strategy of indicator species (cover percentage)" matrix, which formed the basis for the following analyses. We performed ISA on the matrix "relevés $\mathrm{x}$ trait state / strategy (aggregated cover values)", using land use as grouping variable.

We calculated cover-weighted mean values of nitrogen Ellenberg's indicator values for each plot and then performed descriptive statistics for sites A and B.

Statistical analyses were executed using R software (version 3.1.2, R Foundation for Statistical Computing, Vienna, Austria. http://www.R-project.org), and vegan and labdsv R-packages (functions $r d a$ and indval, respectively) (Oksanen et al., 2014).

\section{Results}

Table 1 gives an overview of the dominant species (those with a mean cover value higher than $10 \%$ at least in one of the two sites) with percent frequency and mean cover percentage. The Electronic Appendix 1. shows the whole data set of relevés.

Table 1. Frequency (\%) and mean cover (\%) of species recorded in $0.5 \times 0.5 \mathrm{~m}$ plots in site $A$ (grazed by red deer) and site B (mowed). Only species whose mean cover exceeds $10 \%$ at least in one of the two sites are indicated.

\begin{tabular}{lcccc}
\hline \multirow{2}{*}{ Species } & \multicolumn{3}{c}{ Site A } & \multicolumn{2}{c}{ Site B } \\
\cline { 2 - 5 } & $\begin{array}{c}\text { Frequency } \\
(\%)\end{array}$ & $\begin{array}{c}\text { Mean cover } \\
(\%)\end{array}$ & $\begin{array}{c}\text { Frequency } \\
(\%)\end{array}$ & $\begin{array}{c}\text { Mean cover } \\
(\%)\end{array}$ \\
\hline $\begin{array}{l}\text { Bellardiochloa variegata (Lam.) Kerguélen } \\
\text { Brachypodium rupestre (Host) Roem. \& }\end{array}$ & 53.5 & 18.3 & 20.6 & 3.3 \\
Schult. & 51.2 & 23.6 & 8.8 & 0.3 \\
Deschampsia cespitosa (L.) P. Beauv. & 53.5 & 17.6 & 11.8 & 2.0 \\
Festuca microphylla (St.-Yves) Patzke & 62.8 & 11.1 & 82.4 & 20.5 \\
Festuca pratensis Huds. & 0.0 & 0.0 & 26.5 & 11.3 \\
Trifolium repens L. & 83.7 & 14.4 & 91.2 & 13.2 \\
Leontodon hispidus L. & 0.0 & 0.0 & 85.3 & 14.8 \\
\hline
\end{tabular}

RDA showed a separation between plots of mowed and grazed conditions (Fig. 1). The group of plots undergoing red deer grazing pressure segregated into two clouds: around Deschampsia cespitosa and Bellardiochloa variegata (1), and around Brachypodium rupestre (2). The topographic features shown in Table 2 characterize these two clouds. 


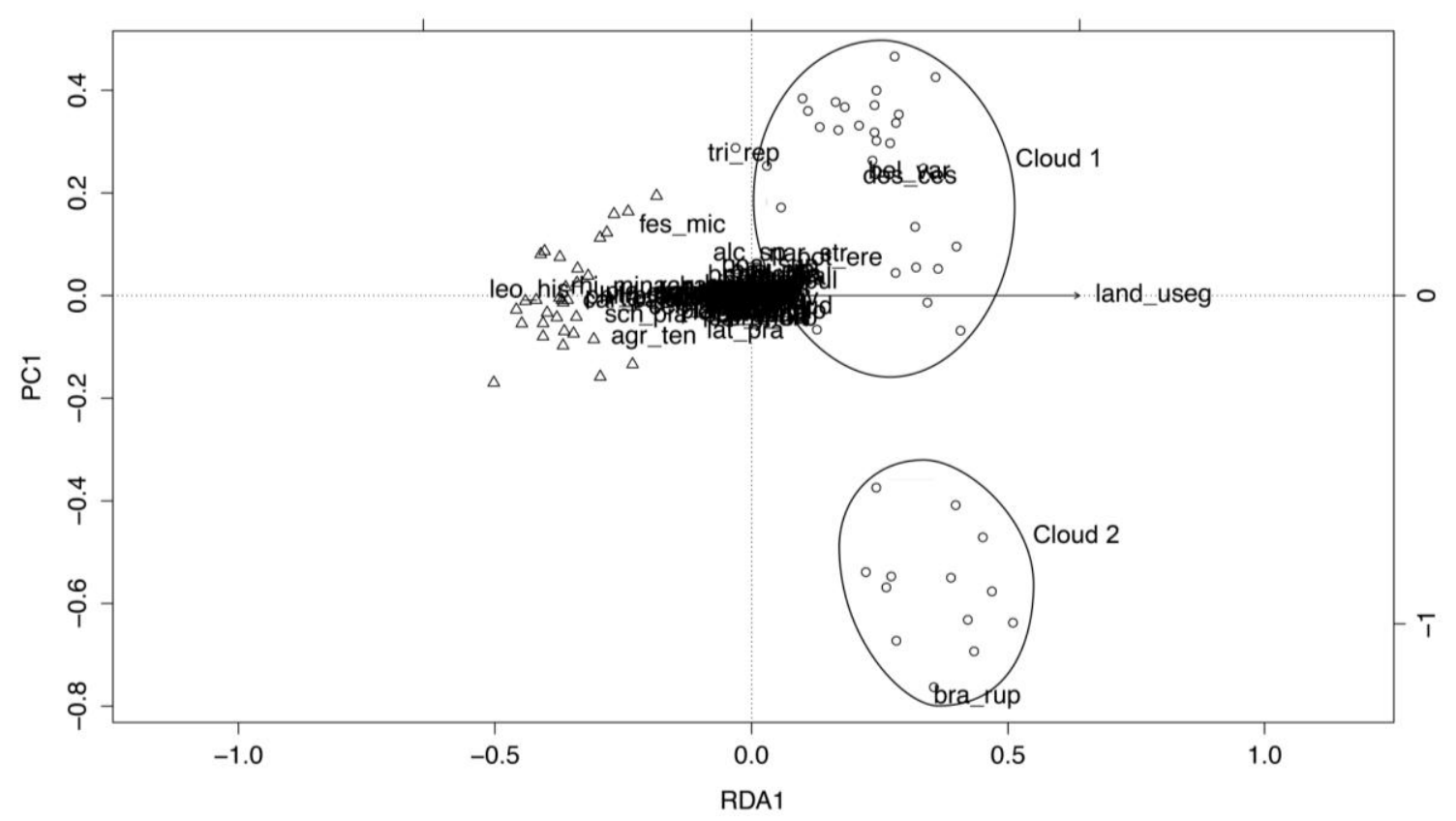

Figure 1. Canonical redundancy analysis (RDA) ordination graph (scaling 2) of the "plots-byspecies cover" matrix, constrained by land use (grazing by red deer / mowing).

(Circles indicate plots laid in the site grazed by red deer, triangles refer to plots laid in the mowed site; land_useg: grazing; agr_ten: Agrostis tenuis; bel_var: Bellardiochloa variegata; bra_rup: Brachypodium rupestre; des_ces: Deschampsia cespitosa; fes_mic: Festuca microphylla; lat_pra: Lathyrus pratensis; leo_his: Leontodon hispidus; sch_pra: Schedonorus pratensis; tri_rep: Trifolium repens).

Table 2. Main topographic features of each group that segregates in the Redundancy analysis ordination graph in the site grazed by red deer.

\begin{tabular}{lrrrrrrr}
\hline $\begin{array}{l}\text { Topographic } \\
\text { features }\end{array}$ & Group & Mean \pm SD & Min. & Max. & $\begin{array}{r}\mathbf{1}^{\text {st }} \\
\text { quartile }\end{array}$ & Median & $\begin{array}{r}\mathbf{3}^{\text {rd }} \\
\text { quartile }\end{array}$ \\
\hline Altitude & 1 & $1490.3 \pm 4.1$ & 1480.0 & 1494.0 & 1490.0 & 1491.0 & 1493.0 \\
(m a.s.1.) & 2 & $1493.0 \pm 5.7$ & 1480.0 & 1501.0 & 1491.0 & 1493.0 & 1495.0 \\
\hline Aspect & 1 & $122.1 \pm 90.4$ & 0.0 & 320.0 & 100.0 & 120.0 & 145.0 \\
(azimuth degree) & 2 & $137.5 \pm 65.2$ & 0.0 & 190.0 & 112.5 & 155.0 & 190.0 \\
\hline Slope & 1 & $6.7 \pm 6.1$ & 0.0 & 30.0 & 2.0 & 5.0 & 10.0 \\
(vertical degree) & 2 & $12.3 \pm 8.1$ & 0.0 & 27.0 & 7.0 & 12.0 & 15.0 \\
\hline
\end{tabular}

SD: standard deviation

Diversity and evenness indices values were greater under mowing (site B) than under grazing (site A) (Table 3).

Table 3. Values of diversity indices calculated for each site (A: grazed by red deer, B: mowed).

\begin{tabular}{cccc}
\hline Site & $\begin{array}{c}\text { Shannon } \\
\left(\mathbf{H}^{\prime}\right)\end{array}$ & $\begin{array}{c}\text { Gini-Simpson } \\
(\mathbf{D})\end{array}$ & Shannon Evenness $\left(\mathbf{E}_{\mathbf{H}}\right)$ \\
\hline A & 1.79 & 0.76 & 0.43 \\
B & 2.35 & 0.86 & 0.50 \\
\hline
\end{tabular}


ISA for species (Table 4) highlighted two sets of indicator species ( 8 for site A and 22 for site B). Species with the highest IV $(P<0.001)$ were Potentilla erecta (0.60), Brachypodium rupestre (0.51), and Deschampsia cespitosa (0.48) for site A; Rhinanthus minor (0.94), Leontodon hispidus (0.85) and Carex caryophyllea (0.82) for site B.

Table 4. List of indicator species of each site, as determined by Indicator species analysis.

Only significant indicator values $(P<0.05)$ higher than 0.20 are shown $(A$ : grazed by red deer, B: mowed).

\begin{tabular}{|c|c|c|c|}
\hline MaxSite & Species & IV & $\boldsymbol{P}$ \\
\hline \multirow{8}{*}{ A } & Bellardiochloa variegata (Lam.) Kerguélen subsp. variegata & 0.454 & 0.001 \\
\hline & Brachypodium rupestre (Host) Roem. \& Schult. & 0.505 & 0.000 \\
\hline & Deschampsia cespitosa (L.) P. Beauv. & 0.480 & 0.000 \\
\hline & Luzula sudetica (Willd.) Schult. & 0.433 & 0.005 \\
\hline & Nardus stricta L. & 0.209 & 0.008 \\
\hline & Potentilla erecta (L.) Räusch. & 0.597 & 0.000 \\
\hline & Thymus pulegioides L. subsp. pulegioides & 0.326 & 0.000 \\
\hline & Veronica officinalis L. & 0.209 & 0.007 \\
\hline \multirow{22}{*}{$\mathrm{B}$} & Achillea millefolium $\mathrm{L}$. & 0.579 & 0.002 \\
\hline & Agrostis capillaris L. & 0.528 & 0.001 \\
\hline & Anthoxanthum odoratum $\mathrm{L}$. & 0.379 & 0.000 \\
\hline & Carex caryophyllea Latourr. & 0.817 & 0.000 \\
\hline & Centaurea nigrescens (Willd.) subsp. transalpina (DC.) Nyman & 0.379 & 0.000 \\
\hline & Colchicum autumnale L. & 0.294 & 0.000 \\
\hline & Crepis aurea (L.) Cass. & 0.324 & 0.000 \\
\hline & Festuca microphylla (St.-Yves) Patzke & 0.533 & 0.010 \\
\hline & Schedonorus pratensis (Huds.) P.Beauv. & 0.265 & 0.000 \\
\hline & Leontodon hispidus L. & 0.853 & 0.000 \\
\hline & Leucanthemum vulgare Lam. & 0.529 & 0.000 \\
\hline & Phleum pratense L. & 0.618 & 0.000 \\
\hline & Plantago lanceolata $\mathrm{L}$. & 0.314 & 0.002 \\
\hline & Plantago media $\mathrm{L}$. & 0.524 & 0.000 \\
\hline & Prunella vulgaris $\mathrm{L}$. & 0.358 & 0.001 \\
\hline & Ranunculus acris L. & 0.316 & 0.022 \\
\hline & Ranunculus montanus Willd. (group) & 0.546 & 0.000 \\
\hline & Rhinanthus minor L. & 0.941 & 0.000 \\
\hline & Taraxacum officinale Weber (group) & 0.644 & 0.000 \\
\hline & Trifolium pratense L. subsp. pratense & 0.570 & 0.000 \\
\hline & Veronica chamaedrys L. subsp. chamaedrys & 0.397 & 0.001 \\
\hline & Vicia cracca $\mathrm{L}$ & 0.326 & 0.017 \\
\hline
\end{tabular}

MaxSite: site with maximum indicator value; IV: indicator value; $P$ proportion of randomized trials with an indicator value equal to or exceeding the observed indicator value

ISA for traits of indicator species (Table 5) highlighted that site A had a low number of indicator traits. Competitive stress-tolerant strategy had the highest IV $(0.81 ; P<$ 0.000) for site A, while Competitors and Competitive Stress-tolerant Ruderals were the preferential strategies of site B. Moreover, ISA indicated rhizome and runner/runnerlike rhizome as vegetative propagation type for site A, while absence of vegetative 
propagation (namely, only sexual reproduction), root, tuber and bulb splitters, besides roots with adventitious buds were identified as indicators for site B. In addition, ISA highlighted a high number of vertical space occupation types (sedge, rosette forbs, hemirosulate upright forbs, prostrate growth form), besides geophytes and therophytes for site B. Instead, chamaephytes, grasses, caespitose and reptant trait states emerged in site A. Finally, graminoids (IV $=0.64 ; P<0.001$ ) were identified as indicators for site A, leguminous plants and forbs for site B $(0.66$ and 0.84 , respectively; $P<0.001)$.

Table 5. List of indicator CSR strategies and trait states for indicator species of each site, as determined by Indicator species analysis. Only significant indicator values $(P<0.05)$ higher than 0.20 are shown (A: grazed by red deer, B: mowed).

\begin{tabular}{|c|c|c|c|c|}
\hline MaxSite & CSR strategy/Trait & Type of CSR strategy/Trait state & IV & $P$ \\
\hline \multirow{8}{*}{ A } & CSR strategy & Competitive stress-tolerators & 0.81 & 0.000 \\
\hline & Life form & Chamaephytes & 0.33 & 0.000 \\
\hline & \multirow{3}{*}{ Vegetative propagation } & Necessary & 0.60 & 0.035 \\
\hline & & Runner/runner-like rhizome & 0.57 & 0.000 \\
\hline & & Rhizome & 0.55 & 0.000 \\
\hline & \multirow{2}{*}{$\begin{array}{l}\text { Horizontal space } \\
\text { occupation }\end{array}$} & Caespitose & 0.69 & 0.002 \\
\hline & & Reptant & 0.57 & 0.024 \\
\hline & $\begin{array}{l}\text { Vertical space } \\
\text { occupation }\end{array}$ & Grass & 0.63 & 0.000 \\
\hline \multirow{14}{*}{ B } & \multirow{2}{*}{ CSR strategy } & Competitors & 0.77 & 0.000 \\
\hline & & Competitive Stress-tolerant Ruderals & 0.60 & 0.004 \\
\hline & \multirow{2}{*}{ Life form } & Geophytes & 0.29 & 0.000 \\
\hline & & Therophytes & 0.93 & 0.000 \\
\hline & \multirow{3}{*}{ Vegetative propagation } & $\begin{array}{l}\text { Not necessary (only sexual } \\
\text { reproduction) }\end{array}$ & 0.92 & 0.000 \\
\hline & & Root, tuber, bulb splitter & 0.75 & 0.000 \\
\hline & & Roots with adventitious buds & 0.64 & 0.000 \\
\hline & \multirow{3}{*}{$\begin{array}{l}\text { Horizontal space } \\
\text { occupation }\end{array}$} & Absent & 0.72 & 0.000 \\
\hline & & Pleiocorm & 0.84 & 0.000 \\
\hline & & Rosulate & 0.94 & 0.000 \\
\hline & \multirow{4}{*}{$\begin{array}{l}\text { Vertical space } \\
\text { occupation }\end{array}$} & Sedge & 0.72 & 0.000 \\
\hline & & Rosette forbs & 0.97 & 0.000 \\
\hline & & Hemirosulate upright forb & 0.80 & 0.000 \\
\hline & & Prostrate & 0.28 & 0.020 \\
\hline
\end{tabular}

MaxSite: cluster with maximum indicator value; IV: indicator value; $P$ proportion of randomized trials with an indicator value equal to or exceeding the observed indicator value

Comparison of cover-weighted means of $\mathrm{N}$ Ellenberg's indicator values between the two sites indicated that soil of site A had a slight lower median value than in site B (3.8 vs. 4.5 - Appendix 2). 


\section{Discussion}

Consistently with several studies (e.g. Adler et al., 2001; Sebastiá et al., 2008; Fontana et al., 2014), we found (Fig. 1) that differences in long-term management lead to different species composition of plant communities. In particular, grazing by red deer promoted differences in species composition in comparison to mowing, leading to lower species diversity and evenness (Table 3). This is consistent with the hypothesized intermediate disturbance intensity produced by mowing (Catorci et al., 2014b), and, following the Grime's statements (2001), indicate that a high stoking rate of red deer should be considered as a heavy disturbance regime. Schütz et al. (2003) found that heavy grazing (about 0.2 individuals/hectare) by red deer led to a significant decrease in tall plant species compared to abandoned grasslands, while the richness and abundance of small size species and species with morphological protection from grazing or short life span increased. Instead, coherently with Augustine and McNaughton (1998) and Bergvall et al. (2006), we observed the opposite trend. In fact, we found a preferential distribution (namely, higher abundance and frequency) of some competitive stresstolerant (indicator life strategy), coarse tall grasses (Bellardiochloa variegata, Brachypodium rupestre, and Deschampsia cespitosa) in the grazed site and of small (low stature) species in the mowed one (Table 3). These contrasting results suggest, consistently with other research (e.g. Gustavson et al., 2007), that the impact of grazing by red deer on pasture richness and composition depends, besides on red deer density, also on the former species composition of sites, and therefore on the land use history. We might argue that grazing by red deer with a high stocking rate has a negative impact on formerly managed meadows, while it is favourable for plant diversity on long-term abandoned grasslands. In fact, grazing by red deer with high stocking rate hinders the spread of successional/ruderal species lacking strong avoidance strategies (as indicated by Schütz et al., 2003), but fosters the establishment of competitive stress-tolerant, dominant tall grasses with strong avoidance strategies. Actually, the coarse tall grasses indicated by ISA for grazed site (Table 4) are poorly palatable species that are generally fostered by improper management due to under- or over-stocking conditions (Louault et al., 2002). Such type of dominant species invests a great amount of resources into root production and foraging rhizomes (indicator trait of the grazed site), overcoming the spatial competition for resources by strong clonal integration strategies (Hutchings and Wijesinghe, 1997). They minimize the loss of resources by the low palatability due to the silica-rich, tough and hairy leaves, the dead leaves protecting the new shoots, etc., and tend to dominate the plant community through specific traits such as tall canopies, extensive lateral spread, and litter deposition (Grime, 2001). Moreover, unpalatable plants typically grow and decompose slowly (Augustine and McNaughton, 1998). Finally, they influence the availability of resources, such as water and nutrient content of soil, and light radiation at the ground level (e.g. Vinton and Burke, 1995; Catorci et al., 2011a).

As a consequence of such strategies, several other species undergo competitive exclusion (Grime, 2001), as demonstrated in the study case by the higher number of indicator species in mowed site (Table 3), where several short graminoids (i.e. Agrostis capillaris, Anthoxanthum odoratum, Carex caryophyllea, Festuca microphylla, Phleum pratense, Schedonorus pratensis) besides forbs, rosette and prostrate plants (i.e. Centaurea nigrescens subsp. transalpina, Crepis aurea, Leontodon hispidus, Taraxacum officinale, etc.) were preferentially distributed (Table 4). 
These results are consistent with previous statements indicating that intermediate disturbance intensity plays a key role in limiting the competitive exclusion of subordinate species by the dominant ones (Grime, 2001). The aforementioned species are CSR or C strategists that were indeed identified by ISA for the mowed site (Table 5). Species with CSR strategy have intermediate characteristics between those of competitors, stress tolerators and ruderals and live in habitats in which coexistence of different strategies is possible because competition, stress and disturbance only occur during particular times in the year (Grime, 2001) or their combined effects are of moderate intensity (Grime, 1977), as under mowing management. This may explain the occurrence of competitors, mostly non-dominant graminoids, which can coexist with CSR strategists because competition for light is less intense.

The highest number of indicator traits was found under mowing management (Table 5 ), while red deer grazing fostered plants with vegetative propagation based on lateral spread of runners and runner-like rhizomes, that are strategies allowing to face heavy disturbance intensity and flower consumption by herbivores (Catorci et al., 2012b). Moreover, such strategies are aimed at maximizing the species competitive ability when there is higher exploitation of soil resources in productive environments, allowing individuals to explore the neighbouring areas and find unexploited soil niches (Friedman and Alpert, 1991). Avoidance strategies like reptant horizontal space occupation and chamaephyte plant life form (Grime, 2001) were fostered as well. In addition, it emerged that grazing strongly reduces the feed value of pastures; actually legumes and forbs, preferentially selected by red deer (Radkowski and BarabaszKrasny, 2007), were indicators of mowed condition. On the other hand, mowing allows the establishment of plants with leaves concentrated at the ground level (prostrate, rosulate), or just above it (hemirosulate), and of geophytes and therophytes, which benefit from canopy removal, thus avoiding competitive exclusion due to light depletion (Catorci et al., 2011b). Moreover, the vegetative reproduction types fostered by mowing (root, tuber and bulb splitters) allow a fast canopy pre-emption and the coexistence with competitive grasses by spatial and temporal niche differentiation in highly productive grassland communities (Catorci et al., 2012a). The observed small difference in nitrogen soil content does not seem to have significant implications from a floristic point of view. It was largely stated that higher the soil nitrogen values higher the spread of competitive tall grasses with a corresponding decrease of the species richness (Grime, 2001). However, we observed the opposite trend, likely indicating that within the observed small range of $\mathrm{N}$ indicator values, the control of dominant tall grasses by mowing has a major impact on species richness.

\section{Features of established competitive tall grasses and management implications}

Table 2 shows that the group of relevés with higher Brachypodium rupestre cover value (group 2 of Fig. 1) was characterized by the driest conditions, indeed it had higher average slope angles and more southerly aspects compared with those with higher cover of Bellardiochloa variegata and Deschampsia cespitosa (group 1 of Fig. 1). Therefore, we can infer that, in the study case, site conditions influence the type of invasive plants but not the spread of competitive species in former meadows undergoing red deer herbivory.

As regards D. cespitosa, its spread in disturbed habitats is largely due to seedling establishment; in closed, more stable communities, seedling establishment is a rare event and the species spreads by clonal growth (Davy, 1980). Thus, the high cover value of this species may be initially due to the trampling by red deer enhancing seed germination, 
subsequently reinforced by its clonal strategy and very low palatability (Davy, 1980). The competitive success of $B$. rupestre is related to its high tiller density and branching frequency (Pottier and Evette, 2010), as well as to its clonal growth and clonal integration strategy capabilities (de Kroon and Bobbink, 1997). These traits allow the spread of this species by the expansion of circular clonal tussocks, which often form (by coalescence of different clonal patches) nearly mono-dominant stands in the final phases of invasion (de Kroon and Bobbink, 1997). The spread of $B$. rupestre is induced by inadequate grazing pressure (Catorci et al., 2012c) and by high content of nitrogen (Willems et al., 1993). $B$. variegata is a poorly palatable species, which can grow on poor and acid soils (with a slow resource acquisition and storage strategy thanks to the presence of rhizomes) and tolerate the competition with tall grasses. Thus, its spread in the grazed site might be a side effect of the spread of $B$. rupestre and D. cespitosa.

In general, with reference to the management of coarse tall grasses, it was demonstrated that overstocking in fenced stands by domestic herbivores may be useful (Catorci et al., 2014a), especially if performed by equines (Catorci et al., 2012b) or cows (Schütz, 2003). Mowing has the same output (Bonanomi et al., 2009). However, mowing alone does not ensure the total control of dominant species endowed with competitive strategies (Catorci et al., 2011b), thus calling for management integration with different type of grazers (Gordon, 1988), such as late summer grazing by very little selective herbivores (i.e. equines).

\section{Conclusion}

We found that in conditions of high stocking rate, red deer significantly affects the species and functional composition of former hay meadows, leading to a trait-related change of species composition. We can also reinforce the hypothesis that the impact of red deer on grassland biodiversity follows the intermediate disturbance hypothesis. Indeed, as postulated by Grime (2001), starting from grassland systems experiencing intermediate, non selective disturbance regimes, red deer grazing reduces the species richness and diversity, mostly by competitive exclusion of subordinate species due to the spread of competitive, stress-tolerant tall grasses with strong avoidance strategies. Thus, we can argue that the substitution of mowing with red deer grazing on former hay meadows is not effective from a biodiversity conservation viewpoint, since palatable species (namely, leguminous plants) and those in need of seasonal canopy removal (e.g. prostrate plants with rosette leaf arrangement or plants with bulbs or tubers) were mostly lost in the long run.

Obviously, the results of the present study, obtained in a small area, are not directly generalizable to every case, but they can indicate the direction of changes of pasture composition from mowed meadows to abandoned lands under high red deer stocking rate, thus contributing to the overall understanding of the impacts due to reed deer population on herbaceous ecosystems. Ultimately, our study suggests that grazing by red deer could trigger the invasion of dominant tall grasses as well as the improper management of domestic herbivores. Moreover, we found some clues that exclusive red deer grazing may lead to the decrease of the pasture feed value, likely causing a decrease of habitat suitability for this ungulate, since animal welfare and reproductive performances are strongly dependent on feed amount and quality (see Catorci et al., 2014a; Lovari et al., 2014). In consideration of the above statements, we suggest that 
red deer impact on grassland composition should be considered in planning red deer population management.

Acknowledgements. The authors wish to thank the "Paneveggio e Pale di S. Martino" Natural Park for the logistic support; the Agenzia Provinciale delle Foreste Demaniali - Ufficio Tecnico e Gestionale (Cavalese - TN) and in particular Dr. Paolo Kovatsch for the permission to conduct research inside the protected area; Mr. Andrea Felicetti for the technical support; Valentina Iesari and Dr. Nicola Postiglione for their help during field survey. The University of Camerino funded the research (University research fund 2013, awarded to A. Catorci).

\section{REFERENCES}

[1] Adler, P., Raff, R., Lauenroth, W. K. (2001): The effect of grazing on the spatial heterogeneity of vegetation. - Oecologia 128: 465-479.

[2] Albon, S. D., Brewer, M. J., O’Brien, S., Nolan, A. J., Cope, D. (2007): Quantifying the grazing impacts associated with different herbivores on rangelands. - Journal of Applied Ecology 44: 1176-1187.

[3] Augustine, D. J., McNaughton, S. J. (1998): Ungulate effects on the functional species composition of plant communities: herbivore selectivity and plant tolerance. - The Journal of Wildlife Management 62: 1165-1183.

[4] Bellu, A., Bugalho, M. N., Monteiro-Henriques, T., Costa, J. C., Rego, F. C. (2012): Habitat use at fine spatial scale: how does patch clustering criteria explain the use of meadows by red deer? - European Journal of Wildlife Research 58: 645-654.

[5] Bergvall, U. A., Rautio, P., Kesti, K., Tuomi, J., Leimar, O. (2006): Associational effects of plant defences in relation to within- and between-patch food choice by a mammalian herbivore: neighbour contrast susceptibility and defence. - Oecologia 147: 253-260.

[6] Bonanomi, G., Caporaso, S., Allegrezza, M. (2009): Effects of nitrogen enrichment, plant litter removal and cutting on a species-rich Mediterranean calcareous grassland. - Plant Biosystems 143: 443-455.

[7] Briske, D. D. (1996): Strategies of plant survival in grazed systems: a functional interpretation. - In: Hodgson, J., Illius, A.W. (eds.) The Ecology and Management of Grazing Systems. CAB International, Wallingford.

[8] Bullock, J. M. (1996): Plant competition and population dynamics. - In: Hodgson, J., Illius, A. W. (eds.) The Ecology and Management of Grazing Systems. CAB International, Wallingford.

[9] Bullock, J. M., Franklin, J., Stevenson, M. J., Silvertown, J., Coulson, S. J., Gregory, S. J., Tofts, R. (2001): A plant trait analysis of responses to grazing in a long-term experiment. - Journal of Applied Ecology 38: 253-267.

[10] Caccianiga, M., Luzzaro, A., Pierce, S., Ceriani, M. R., Cerabolini, B. (2006): The functional basis of a primary succession resolved by CSR classification. - Oikos 112: 1020.

[11] Catorci, A., Antolini, E., Tardella, F. M., Scocco, P. (2014a): Assessment of interaction between sheep and poorly palatable grass: a key tool for grassland management and restoration. - Journal of Plant Interactions 9: 112-121.

[12] Catorci, A., Cesaretti, S., Gatti, R., Ottaviani, G. (2011a): Abiotic and biotic changes due to spread of Brachypodium genuense (DC.) Roem. \& Schult. in sub-Mediterranean meadows. - Community Ecology 12: 117-125.

[13] Catorci, A., Cesaretti, S., Gatti, R., Tardella, F. M. (2012a): Trait-related flowering patterns in submediterranean mountain meadows. - Plant Ecology 213: 1315-1328. 
[14] Catorci, A., Cesaretti, S., Malatesta, L., Tardella, F. M. (2014b): Effects of grazing vs mowing on the functional diversity of sub-Mediterranean productive grasslands. Applied Vegetation Science 17: 658-669.

[15] Catorci, A., Gatti, R., Cesaretti, S. (2012b): Effect of sheep and horse grazing on species and functional composition of sub-Mediterranean grasslands. - Applied Vegetation Science 15: 459-469.

[16] Catorci, A., Ottaviani, G., Cesaretti, S. (2011b): Functional and coenological changes under different long-term management conditions in Apennine meadows (central Italy). Phytocoenologia 41: 45-58.

[17] Catorci, A., Ottaviani, G., Vitasović Kosić, I., Cesaretti, S. (2012c): Effect of spatial and temporal patterns of stress and disturbance intensities in a sub-Mediterranean grassland. Plant Biosystems 146: 352-367.

[18] Chollet, S., Baltzinger, C., Ostermann, L., Saint-André, F., Martin, J. L. (2013): Importance for forest plant communities of refuges protecting from deer browsing. Forest Ecology and Management 289: 470-477.

[19] Conti, F., Abbate, G., Alessandrini, A., Blasi, C. (2005): An annotated checklist of the Italian vascular flora. - Palombi, Roma.

[20] Cornelissen, J.H.C., Lavorel, S., Garnier, E., Díaz, S., Buchmann, N., Gurvich, D. E., Reich, P. B., ter Steege, H., Morgan, H. D., van der Heijden, M. G. A., et alii (2003): A handbook of protocols for standardised and easy measurement of plant functional traits worldwide. - Australian Journal of Botany 51: 335-380.

[21] Cote, S. D., Rooney, T. P., Tremblay, J. P., Dussault, C., Waller, D. M. (2004): Ecological impacts of deer overabundance. - Annual Review of Ecology, Evolution, and Systematics 35: 113-147.

[22] Cougenhour, M. B. (1991): Spatial components of plant-herbivore interactions in pastoral, ranching, and native ungulate ecosystems. - Journal of Range Management 44: 530-542.

[23] Davy, A. J. (1980): Deschampsia caespitosa (L.) Beauv. (Aira cespitosa L., Deschampsia cespitosa (L.) Beauv.). - Journal of Ecology 68: 1075-1096.

[24] de Kroon, H., Bobbink, R. (1997): Clonal plant performance under elevated nitrogen deposition, with special reference to Brachypodium pinnatum in chalk grassland. - In: de Kroon, H., Van Groenendael, J. (eds.) The Ecology and Evolution of Clonal Plants. Backhuys Publishers, Leiden.

[25] Dufrêne, M., Legendre, P. (1997): Species assemblages and indicator species: the need for a flexible asymmetrical approach. - Ecological monographs 67: 345-366.

[26] Ferretti, F., Corazza, M., Campana, I., Pietrocini, V., Brunetti, C., Scornavacca, D., Lovari, S. (2015): Competition between wild herbivores: reintroduced red deer and Appennine chamois. - Behavioral Ecology 26: 550-559.

[27] Ellenberg, H. (1974): Zeigerwerte der Gefasspflanzen Mitteleuropas. - Scripta Geobotanica 9: 1-97.

[28] Ellenberg, H. (1996): Vegetation Mitteleuropas mit den Alpen (5 ${ }^{\text {th }}$ edition). Eugen Ulmer, Stuttgart.

[29] Ellenberg, H., Weber, H. E., Dull, R., Wirth, V., Werner, W., Paulißen, D. (1992): Zeigerwerte von Pflanzen in Mitteleuropa. - Scripta Geobotanica 18: 1-258.

[30] Fontana, V., Radtke, A., Walde, J., Tasser, E., Wilhalm, T., Zerbe, S., Tappeiner, U., (2014): What plant traits tell us: consequences of land use change of a traditional agroforest system on biodiversity and eco system services provision. - Agriculture Ecosystems and Environment 186: 44-53.

[31] Friedman, D., Alpert, P. (1991): Reciprocal transport between ramets increases growth in Fragaria chiloensis when light and nitrogen occur in separate patches but only if patches are rich. - Oecologia 86: 76-80.

[32] Garnier, E., Lavorel, S., Ansquer, P., Castro, H., Cruz, P., Dolezal, J., et allii (2007): Assessing the effects of land-use change on plant traits, communities and ecosystem 
functioning in grasslands: a standardized methodology and lessons from an application to 11 European sites. - Annals of botany 99: 967-985.

[33] Gill, R. M. A., Beardall, V. (2001): The impact of deer on woodlands: the effects of browsing and seed dispersal on vegetation structure and composition. - Forestry 74: 209218.

[34] Godefroid, S., Dana, E. D. (2007): Can Ellenberg's indicator values for mediterranean plants be used outside their region of definition? - Journal of Biogeography 34: 62-68.

[35] Gordon, I. J. (1988): Facilitation of red deer grazing by cattle and its impact on red deer performance. - Journal of Applied Ecology 25: 1-10.

[36] Grime, J. P. (1974): Vegetation classification by reference to strategies. - Nature 250: 26-31 .

[37] Grime, J. P. (1977): Evidence for the existence of three primary strategies in plants and its relevance to ecological and evolutionary theory. - American Naturalist 111: 11691194.

[38] Grime, J. P. (2001): Plant Strategies, Vegetation Processes and Ecosystem Properties. 2nd ed. - Wiley \& Sons Ltd., Chichester.

[39] Grime, J. P., Hodgson, J. G., Hunt, R. (1988): Comparative Plant Ecology: a Functional Approach to Common British Species. - Unwin Hyman, London.

[40] Gustavsson, E., Lennartsson, T., Emanuelsson, M. (2007): Land use more than 200 years ago explains current grassland plant diversity in a Swedish agricultural landscape. Biological Conservation 138: 47-59.

[41] Hegland, S. J., Lilleeng, M. S., Moe, S. R. (2013): Old-growth forest floor richness increases with red deer herbivory intensity. - Forest Ecology and Management 310: 267274.

[42] Hester, A. J., Gordon, I. J., Baillie, G. J., Tappin, E. (1999): Foraging behaviour of sheep and red deer within natural heather/grass mosaics. - Journal of Applied Ecology 36: 133146.

[43] Hofmann, R. R. (1989): Evolutionary steps of ecophysiological adaptation and diversification of ruminants: a comparative view of their digestive system. - Oecologia 78: 443-457.

[44] Holdo, R. M., Holt, R. D., Coughenour, M. B., Ritchie, M. E. (2007): Plant productivity and soil nitrogen as a function of grazing, migration and fire in an African savanna. Journal of Ecology 95: 115-128.

[45] Hutchings, M.J., Wijesinghe, D. K. (1997): Patchy habitats, division of labour and growth dividends in clonal plants. - Trends in Ecology \& Evolution 12: 390-394.

[46] Johnson, C., Parker, K., Heard, D. (2001): Foraging across a variable landscape: behavioral decisions made by woodland caribou at multiple spatial scales. - Oecologia 127: 590-602.

[47] Kay, R. N. B. (1985): Comparative studies of food propulsion in ruminants. - In: Ooms, L.A., Degryse, A.D., Marsboom, R. (eds.) The ruminant stomach. Proceed Int Workshop Antwerpen.

[48] Klaus, V. H., Kleinebecker, T., Boch, S., Müller, J., Socher, S. A., Prati, D., Fischer, M., Hölzel, N. (2012): NIRS meets Ellenberg's indicator values: prediction of moisture and nitrogen values of agricultural grassland vegetation by means of near-infrared spectral characteristics. - Ecological Indicators 14: 82-86.

[49] Klimešová, J., de Bello, F. (2009): Clo-Pla: the database of clonal and bud bank traits of Central European flora. - Journal of Vegetation Science 20: 511-516.

[50] Klimešová, J., Klimeš, L. (2006): CLO-PLA3: a database of clonal growth architecture of Central European plants. Available from: http://clopla.butbn.cas.cz. Accessed 20 January 2014

[51] Klotz, S., Kühn, I., Durka, W. (2002): Biolflor: Eine Datenbank zu biologischökologischen Merkmalen der Gefäßpflanzen in Deutschland [BiolFlor: A database on bio-ecological characteristics of vascular plants in Germany]. - Schriftenreihe für 
Vegetationskunde 38. Bonn. Bundesamt für Naturschutz Accessed 10 Jan 2014. Available from: http://www.ufz.de/biolflor/index.jsp

[52] Kohler, B., Gigon, A., Edwards, P. J., Krusi, B., Langenauer, R., Luscher, A., Ryser, P. (2005): Changes in the species composition and conservation value of limestone grasslands in Northern Switzerland after 22 years of contrasting managements. Perspectives on Plant Ecology, Evolution and Systematics 7: 51-67.

[53] Krumbiegel, A. (2002): Morphologie der vegetative Organe (auser Blatter). - In: Klotz, S., Kühn, I., Durka, W. (eds.) Biolflor: Eine Datenbank zu biologischökologischen Merkmalen der Gefäßpflanzen in Deutschland. Schriftenreihe für Vegetationskunde 38, Bonn.

[54] Lauenroth, W. K., Aguilera, M. O. (1998): Plant-plant interactions in grasses and grasslands. - In: Cheplick, G. P. (ed.) Population Biology of Grasses. Cambridge University Press, Cambridge.

[55] Lavorel, S., McIntyre, S., Landsberg, J., Forbes, T. D. A. (1997): Plant functional classifications: from general groups to specific groups based on response to disturbance. Trends in Ecology \& Evolution 12: 474-478.

[56] Legendre, P., Gallagher, E.D. (2001): Ecologically meaningful transformations for ordination of species data. - Oecologia 129: 271-280.

[57] Liira, J., Zobel, K. (2000): Vertical structure of a species-rich grassland canopy, treated with additional illumination, fertilization and mowing. - Plant Ecology 146: 185-195.

[58] Louault, F., Soussana, J. F., Perrodin, M. (2002): Long-term effects of a reduced herbage use in a semi-natural grassland. I. Plant functional traits and plant response groups. Grassland Science in Europe 7: 338-339.

[59] Lovari, S., Ferretti, F., Corazza, M., Minder, I., Troiani, N., Ferrari, C., Saddi, A. (2014): Unexpected consequences of reintroductions: competition between increasing red deer and threatened Apennine chamois. - Animal Conservation 17: 359-370.

[60] Marchiori, E., Sturaro, E., Ramanzin, M. (2012): Wild red deer (Cervus elaphus) grazing may seriously reduce forage production in mountain meadows. - Italian Journal of Animal Science 11: 47-53.

[61] McCollin, D., Moore, L., Sparks, T. (2000): The flora of a cultural landscape: environmental determinants of change revealed using archival sources. - Biological Conservation 92: 249-263.

[62] McCune, B., Grace, J. B. (2002): Analysis of ecological communities. - MjM Software Design, Gleneden Beach.

[63] Mysterud, A. (2006): The concept of overgrazing and its role in management of large herbivores. - Wildlife Biology 12: 129-141.

[64] Noble, I., Gitay, H. (1996): A functional classification for predicting the dynamics of landscapes. - Journal of Vegetation Science 7: 329-336.

[65] Oksanen, J., Guillaume Blanchet, F., Kindt, R., Legendre, P., Minchin, P. R., O'Hara, R. B., Simpson, G. L., Solymos, P., Stevens, M. H. H., Wagner, H. (2014): vegan: Community Ecology Package. $\mathrm{R}$ package version 2.2-0. http://CRAN.Rproject.org/package= =vegan

[66] Pignatti, S. (1982): Flora d'Italia. - Edagricole, Bologna.

[67] Pignatti, S. (2005): Biondicazione attraverso le piante vascolari. Valori di indicazione secondo Ellenberg (Zeigerwerte) per le specie della Flora d'Italia. - Braun Blanquetia 39: 1-97.

[68] Pottier, J., Evette, A. (2010): On the relationship between clonal traits and small-scale spatial patterns of three dominant grasses and its consequences on community diversity. Folia Geobotanica 45: 59-75.

[69] Putman, R.J., Langbein, J., Green, P., Watson, P. (2011): Identifying threshold densities for wild deer in the UK above which negative impacts may occur. - Mammal Review 41: 175-196. 
[70] Radkowski, A., Barabasz-Krasny, B. (2007): Botanical analysis of fallow grassland existing in mountain conditions - Acta Agrobotanica 60: 165-173.

[71] Raunkiaer, C., (1934): The life forms of plants and statistical plant geography. - Oxford University Press, Oxford

[72] Rooney, T.P., Waller, D.M. (2003): Direct and indirect effects of white-tailed deer in forest ecosystems. - Forest Ecology and Management 181: 165-176.

[73] Sebastià, M. T., de Bello, F., Puig, L., Taull, M. (2008): Grazing as a factor structuring grasslands in the Pyrenees. - Applied Vegetation Science 11: 215-222.

[74] Scocco, P., Mercati, F., Brusaferro, A., Ceccarelli, P., Belardinelli, C., Malfatti, A. (2013): Keratinization degree of rumen epithelium and body condition score in sheep grazing on Brachipodiumrupestre. - Veterinaria Italiana 49: 211-217.

[75] Skarpe, C., Hester, A. J. (2008): Plant traits, browsing and gazing herbivores, and vegetation dynamics. - In: Gordon, I. J., Prins, H. H. T. (eds.) The ecology of browsing and grazing. Springer, Berlin.

[76] Schütz, M., Risch, A., Leusinger, E., Krusil, B. O., Achermann, G. (2003): Impact of herbivory by red deer (Cervus elaphus) on pattern and processes in subalpine grasslands in the swiss National Park. - Forest Ecology and Management 181: 177-188.

[77] van der Werf, A., Geerts, R. H. E. M., Jacobs, F. H. H., Korevaar, H., Oomes, M. J. M., De Visser, W. (1998): The importance of relative growth rate and associated traits for competition between species during vegetation succession. - In: Lambers, H., Poorter, H., van Vuuren, M. M. I. (eds.) Inherent variation in plant growth. Physiological mechanisms and ecological consequences. Backhuys.

[78] Vinton, M. A., Burke, I. C. (1995): Interactions between individual plant species and soil nutrient status in shortgrass steppe. - Ecology 76: 1116-1133.

[79] WallisDeVries, M. F., Laca, E. A., Demment, M. W. (1999): The importance of scale of patchiness for selectivity in grazing herbivores. - Oecologia 121: 355-363.

[80] Wieren, S. E., Bakker, J. P. (2008): The impact of browsing and grazing herbivores on biodiversity. - In: Gordon, I. J., Prins, H. H. T. (eds.) The ecology of browsing and grazing. Springer, Berlin.

[81] Willems, J. H., Peet, R. K., Bik, L. (1993): Changes in chalk-grassland structure and species richness resulting from selective nutrient additions. - Journal of Vegetation Science 4: 203-212. 


\section{APPENDIX}

Appendix 1. Traits and trait states analysed in the present study, with a brief description, the main associated plant functions, and data sources.

\begin{tabular}{|c|c|c|c|c|}
\hline Trait & Trait state & Description & $\begin{array}{l}\text { Main plant } \\
\text { functions }\end{array}$ & Data source \\
\hline Life form & $\begin{array}{l}\text { Hemicryptophyte, } \\
\text { Chamaephyte, Geophyte, } \\
\text { Therophyte }\end{array}$ & $\begin{array}{l}\text { Location of perennating } \\
\text { organs as an adaptation } \\
\text { used by plants to } \\
\text { overcome the adverse } \\
\text { seasons, according to } \\
\text { Raunkiaer (1934) } \\
\text { classification }\end{array}$ & $\begin{array}{l}\text { Competitive ability } \\
\text { Response to soil } \\
\text { resources } \\
\text { Response to } \\
\text { disturbance }\end{array}$ & $\begin{array}{l}\text { Pignatti (1982); } \\
\text { checked by } \\
\text { authors' } \\
\text { observations }\end{array}$ \\
\hline $\begin{array}{l}\text { Vegetative } \\
\text { propagation }\end{array}$ & $\begin{array}{l}\text { Necessary/not necessary } \\
\text { (only sexual reproduction); } \\
\text { rhizome; runner/runner-like } \\
\text { rhizome; root with } \\
\text { adventitious buds; bulbils; } \\
\text { root, tuber or bulb splitter }\end{array}$ & $\begin{array}{l}\text { Occurrence and type of } \\
\text { vegetative propagation, } \\
\text { identified following } \\
\text { Krumbiegel (2002), and } \\
\text { Klimešová and de Bello } \\
\text { (2009) }\end{array}$ & $\begin{array}{l}\text { Competitive ability } \\
\text { Response to soil } \\
\text { resources } \\
\text { Response to } \\
\text { disturbance } \\
\text { Reproduction }\end{array}$ & $\begin{array}{l}\text { Klotz et al. (2002), } \\
\text { Klimešová and } \\
\text { Klimeš (2006), } \\
\text { checked and } \\
\text { supplemented by } \\
\text { authors' } \\
\text { observations }\end{array}$ \\
\hline $\begin{array}{l}\text { Horizontal } \\
\text { space } \\
\text { occupation }\end{array}$ & $\begin{array}{l}\text { Caespitose (tuft forming); } \\
\text { pleiocorm (system of } \\
\text { compact, perennial shoots } \\
\text { occurring at the proximal end } \\
\text { of the persistent primary } \\
\text { root); reptant (shoots and/or } \\
\text { stems creeping on the } \\
\text { ground); prostrate; rosulate } \\
\text { (leaves basally arranged } \\
\text { forming a rosette); absence of } \\
\text { horizontal space occupation }\end{array}$ & $\begin{array}{l}\text { Classification of } \\
\text { horizontal growth form, } \\
\text { according to the } \\
\text { categories indicated in } \\
\text { Krumbiegel (2002) }\end{array}$ & $\begin{array}{l}\text { Competitive ability } \\
\text { Response to soil } \\
\text { resources } \\
\text { Response to } \\
\text { disturbance } \\
\text { Defence from } \\
\text { herbivory }\end{array}$ & $\begin{array}{l}\text { Pignatti (1982), } \\
\text { Klotz et al. (2002); } \\
\text { checked and } \\
\text { supplemented by } \\
\text { authors' } \\
\text { observations }\end{array}$ \\
\hline $\begin{array}{l}\text { Vertical } \\
\text { space } \\
\text { occupation }\end{array}$ & $\begin{array}{l}\text { Leafy stem, narrow leaves } \\
\text { (grass); no leafy stem, narrow } \\
\text { basal leaves (sedge); upright } \\
\text { forb with leaves arranged } \\
\text { either scattered or tightly } \\
\text { packed at the shoot, thus with } \\
\text { short and long internodes } \\
\text { (hemirosulate upright forb); } \\
\text { upright forb with leaves } \\
\text { equally spaced along the stem } \\
\text { (erosulate upright forb); no } \\
\text { leafy stem, broad basal leaves } \\
\text { (rosette forb); leafy stem } \\
\text { prostrate on the ground } \\
\text { (prostrate forb) }\end{array}$ & $\begin{array}{l}\text { Classification based on } \\
\text { the width of leaves and } \\
\text { on their position along } \\
\text { the stem (Liira and } \\
\text { Zobel, 2000; } \\
\text { Krumbiegel, } 2002 \\
\text { modified) }\end{array}$ & $\begin{array}{l}\text { Competitive ability } \\
\text { Response to soil } \\
\text { resources } \\
\text { Response to } \\
\text { disturbance } \\
\text { Defence from } \\
\text { herbivory }\end{array}$ & $\begin{array}{l}\text { Pignatti (1982), } \\
\text { Klotz et al. (2002); } \\
\text { checked and } \\
\text { supplemented by } \\
\text { authors' } \\
\text { observations }\end{array}$ \\
\hline
\end{tabular}


Appendix 2. Descriptive statistics of cover-weighted mean nitrogen Ellenberg's indicator value in site A (grazed by red deer) and in site B (mowed).

\begin{tabular}{lcc}
\hline Statistics & Site A & Site B \\
\hline Min & 2.7 & 3.1 \\
$1^{\text {st }}$ quartile & 3.5 & 3.7 \\
Median & 3.8 & 4.5 \\
$3^{\text {rd }}$ quartile & 4.1 & 5.1 \\
Max & 6.2 & 7.1 \\
Mean & 3.8 & 4.5 \\
Standard deviation & 0.6 & 0.9 \\
\hline
\end{tabular}

\section{ELECTRONIC APPENDIX}

Electronic Appendix 1: Species cover values (\%) recorded in 50 x $50 \mathrm{~cm}$ plots laid in site A (grazed by red deer) and site $B$ (mowed). 